\title{
SLUDGE BATCH 2/3 BLEND SRAT CYCLE IN THE SRNL SHIELDED CELLS
}

\author{
C. J. Bannochie \\ J. M. Pareizs \\ D. C. Koopman
}

May 2004

Immobilization Technology Section

Savannah River National Laboratory

Aiken, SC 29808 
This document was prepared in conjunction with work accomplished under Contract No. DE-AC09-96SR18500 with the U. S. Department of Energy.

\section{DISCLAIMER}

This report was prepared as an account of work sponsored by an agency of the United States Government. Neither the United States Government nor any agency thereof, nor any of their employees, makes any warranty, express or implied, or assumes any legal liability or responsibility for the accuracy, completeness, or usefulness of any information, apparatus, product or process disclosed, or represents that its use would not infringe privately owned rights. Reference herein to any specific commercial product, process or service by trade name, trademark, manufacturer, or otherwise does not necessarily constitute or imply its endorsement, recommendation, or favoring by the United States Government or any agency thereof. The views and opinions of authors expressed herein do not necessarily state or reflect those of the United States Government or any agency thereof.

This report has been reproduced directly from the best available copy.

Available for sale to the public, in paper, from: U.S. Department of Commerce, National Technical Information Service, 5285 Port Royal Road, Springfield, VA 22161, phone: (800) 553-6847, fax: (703) 605-6900

email: orders@ntis.fedworld.gov

online ordering: http://www.ntis.gov/help/index.asp

Available electronically at http://www.osti.gov/bridge

Available for a processing fee to U.S. Department of Energy and its contractors, in paper, from: U.S. Department of Energy, Office of Scientific and Technical Information, P.O. Box 62, Oak Ridge, TN 37831-0062,

phone: (865)576-8401,

fax: (865)576-5728

email: $\underline{\text { reports@ adonis.osti.gov }}$ 


\title{
SLUDGE BATCH 2/3 BLEND SRAT CYCLE IN THE SRNL SHIELDED CELLS
}

\author{
C. J. Bannochie \\ J. M. Pareizs \\ D. C. Koopman
}

May 2004

Immobilization Technology Section Savannah River National Laboratory Aiken, SC 29808 
This page was intentionally left blank 


\section{EXECUTIVE SUMMARY}

The work conducted for this report was done to determine whether any processing problems could be anticipated with the blended material from Tank 40 and 51. The purpose of this report is to document the results of a SB2/3 blend SRAT cycle performed at the SRNL Shielded Cells Facility (SCF).

The following items are documented in this report:

- Preparation of a SB2/3 blend slurry.

- Characterization of the SB2/3 blend slurry.

- A demonstration of the DWPF Sludge Receipt and Adjustment Tank (SRAT) cycle using SB2/3 blend slurry.

- Comparison of the SB2/3 blend slurry results with those obtained for the SB3 Qualification.

The following conclusions are drawn from this work:

- The SB2/3 blend supernate has a surface tension significantly higher than SB2 simulants and close to that of water.

- SB2/3 blend rheology is slightly more viscous and visually more cohesive than a SB3 sample alone.

- SRAT cycle processing of a SB2/3 blend was accomplished with no significant issues. Nitrite was destroyed at $140 \%$ of acid stoichiometry. Hydrogen generation was well within DWPF limits. Nitrous oxide generation was well within DWPF limits.

- Considerable soluble uranium was measured in the SRAT product, likely as a result of the final $\mathrm{pH}$ of the SRAT product.

- $\mathrm{SB} 2 / 3$ blend SRAT product is less viscous than the starting feed with both the consistency and yield stress below the recommended DWPF operating region.

The demonstration of simulated DWPF SRAT cycle processing of a radioactive SB2/3 blend based upon the expected tank volume ratios, at the time of the experimentation, in the SRNL Shielded Cells was accomplished successfully. It is recommended that DWPF could process a SB2/3 blend corresponding to that tested without issues related to off-gas generation in the SRAT.

Appreciable soluble uranium was found in the SRAT product. Initially this level of soluble uranium was believed to not have been previously observed, but we now believe it may be that it was not commonly measured or when it was measured, the final SRAT product $\mathrm{pH}$ was above 6 and appreciable soluble $\mathrm{U}$ was not produced. The source of this soluble uranium is not due solely to the simulated H-canyon plutonium transfer adjustments made to the SB3 Qualification sample prior to processing, since this accounts for only about $9 \%$ of the total uranium. Yet unpublished results from the study on the impact of uranium in SB2 processing indicate that freshly precipitated uranium is no more likely to be solubilized as a result of SRAT processing. The source of the soluble uranium is likely related to the final $\mathrm{pH}$ of the SRAT product rather than the relative age of the uranium species present.

It is prudent to process a sample of the final Tank 40/51 SB3 feed prepared in the Tank Farm when it becomes available later this FY to evaluate any processing issues and to determine the impact of the actual solids level on nitrite destruction. Simulant runs with higher solids levels could not destroy the nitrite at the same acid stoichiometry. 
TABLE OF CONTENTS

EXECUTIVE SUMMARY

iii

LIST OF FIGURES

$\mathrm{V}$

LIST OF TABLES

LIST OF ACRONYMS

1.0 INTRODUCTION AND BACKGROUND

2.0 SLUDGE BATCH 2/3 BLEND

2.1 Approach

2.2 Results

2.2.1 Rheological Measurements on SB2/3 Blend

2.2.2 Surface Tension Measurements

2.2.3 SRAT Cycle Feed Characterization

$\mathrm{V}$

3.0 SRAT CYCLE

3.1 Approach

3.1.1 Equipment Set-Up

3.1.2 Acid Calculations for the SRAT Cycle $\quad 10$

$\begin{array}{ll}\text { 3.1.3 Description of SRAT Cycle } & 12\end{array}$

3.2 Results

3.2.1 SRAT Cycle Product Characterization 13

3.2.2 Off-Gas Generation 15

3.2.3 Nitrite, Formate, and Oxalate Destruction 18

3.2.4 Elements Dissolved From the Sludge During the SRAT Cycle 18

$\begin{array}{ll}\text { 3.2.5 Rheological Data on SB2/3 SRAT Product } & 19\end{array}$

4.0 CONCLUSIONS

5.0 RECOMMENDATIONS/PATH FORWARD 23

6.0 REFERENCES $\quad 25$

7.0 ACKNOWLEDGEMENTS 27

APPENDIX A. OUTLINE OF ANALYTICAL METHODS 29 


\section{LIST OF FIGURES}

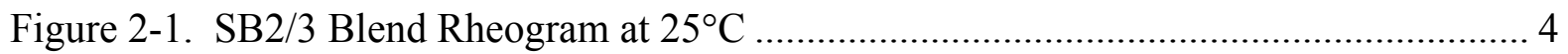

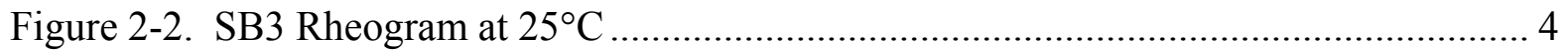

Figure 2-3. Model Predictions of Rheological Behavior for SB2/3 Blend (Up-Curves)......... 5

Figure 2-4. Blending Model Up-Curve Fits for a Bingham Plastic ...................................... 5

Figure 3-1. Photograph of 1-L SRAT Vessel in SRNL Shielded Cells Mockup Area............ 9

Figure 3-2. Gas Generation during the SB2/3 SRAT Cycle.............................................. 16

Figure 3-3. Comparison of SB2/3 and SB3 SRAT Cycle Hydrogen Generation Rates ........ 17

Figure 3-4. Effect of $\mathrm{pH}$ on Soluble Levels of $\mathrm{Ca}, \mathrm{Mg}, \mathrm{Mn}$ and $\mathrm{Ni}$.................................... 19

Figure 3-5. SB2/3 Blend SRAT Product Rheograms at $25^{\circ} \mathrm{C}$.............................................. 19

\section{LIST OF TABLES}

Table 2-1. Mass of Each Sludge Batch and the Final Blend Volume Percent Ratio.......................

Table 2-2. Summary of the Rheology Results Obtained from the SB2, SB2/3 Blend, and SB3 Sludge Slurry Samples Compared to the DWPF Operating Region ..............................

Table 2-3. Surface Tension of Various Materials .............................................................................

Table 2-4. Weight Percent Solids and Density of the SB2/3 Blend Sample ..................................6

Table 2-5. Anions, Base Equivalents, $\mathrm{pH}$ and TIC Results in the SB2/3 Blend ...........................

Table 2-6. Comparison of Selected Measured Properties of SB2 (2003), SB3 Qualification, and SB2/3 Blend Samples (mg/kg slurry) ............................................................

Table 2-7. Elements in the SB 2/3 Blend SRAT Cycle Feed ......................................................

Table 3-1. Summary of Input and Output for the SB2/3, SB2 (2003), and SB3 Qualification Shielded Cells SRAT Cycle Acid Calculations..........................................................12

Table 3-2. DWPF and SRNL Scale SRAT Processing Parameters and Acid Addition Amounts .......................................................................................................13

Table 3-3. Weight Percent Solids, Density, and Final pH of the SRAT Cycle Product Using the SB2/3 Blend Sample

Table 3-4. Measured Ion Chromatography Anions in the SB2/3 Blend SRAT Product ...............14

Table 3-5. Elements in the SB2/3 Blend SRAT Product..........................................................15

Table 3-6. Maximum Observed DWPF Scale Hydrogen, Carbon Dioxide, and Nitrous Oxide Concentrations and Generation Rates During the SB2/3 SRAT Cycle in the SRNL Shielded Cells ................................................................................................16

Table 3-7. Comparison of Noble Metal Levels between SB2 and SB3 Qualification Samples...17

Table 3-8. SRAT Cycle Nitrite to Nitrate Conversion, Percent Formate Destruction, and Percent Oxalate Destruction and Comparison to Acid Calculation Assumptions.......18

Table 3-9. Percent of Elements Soluble in the SRAT Cycle Feed and Product .............................18 


\section{LIST OF ACRONYMS}

$\begin{array}{ll}\text { ACTL } & \text { Aiken County Technical Laboratory } \\ \text { ADS } & \text { Analytical Development Section } \\ \text { ASP } & \text { Analytical Study Plan } \\ \text { ARP } & \text { Actinide Removal Process } \\ \text { DI } & \text { Deionized water } \\ \text { DWPF } & \text { Defense Waste Processing Facility } \\ \text { I } & \text { Ionic Strength } \\ \text { IC } & \text { Ion chromatograph } \\ \text { ICP-AES } & \text { Inductively coupled plasma - atomic emission spectroscopy } \\ \text { L } & \text { Liter } \\ \text { SB2 } & \text { Sludge Batch 2 } \\ \text { SB3 } & \text { Sludge Batch 3 } \\ \text { SB2/3 } & \text { Sludge Batch 2/3 (Blend) } \\ \text { Sccm } & \text { standard cubic centimeters per minute } \\ \text { scfm } & \text { standard cubic feet per minute } \\ \text { SCF } & \text { Shielded Cells Facility (SRNL) } \\ \text { SME } & \text { Slurry Mix Evaporator } \\ \text { SMRF } & \text { Slurry-Fed Melt Rate Furnace } \\ \text { SRAT } & \text { Sludge Receipt Adjustment Tank } \\ \text { SRNL } & \text { Savannah River National Laboratory } \\ \text { TTQAP } & \text { Task Technical and Quality Assurance Plan } \\ \text { TTR } & \text { Technical Task Request }\end{array}$




\subsection{INTRODUCTION AND BACKGROUND}

The Defense Waste Processing Facility (DWPF) will process the next sludge batch (Sludge Batch 3 (SB3)) after combining the contents of Tank 51 with the remainder of Sludge Batch 2 (SB2) in Tank 40 along with a $\mathrm{Np}$ stream from H-canyon. The composition of SB3 material used in this study was that prepared in the Savannah River National Laboratory (SRNL) Shielded Cells and described in the Sludge Batch 3 Qualification report ${ }^{1}$.

The work conducted for this report was done to determine whether any processing problems could be anticipated with the blended material from Tank 40 and 51. The purpose of this report is to document the results of a SB2/3 blend SRAT cycle performed at the SRNL Shielded Cells Facility (SCF). This work is governed by two Technical Task Requests (TTR) HLW/DWPF/TTR-02-0035 ${ }^{2}$ and HLW/DWPF/TTR-03-0005 $5^{3}$, two Task Technical and Quality Assurance Plans (TTQAP) ${ }^{4,5}$, and an existing Analytical Study Plan (ASP) ${ }^{6}$ was used for guidance on sample analyses.

Documented in this report are:

- Preparation of a SB2/3 blend slurry.

- Characterization of the SB2/3 blend slurry.

- A demonstration of the DWPF Sludge Receipt and Adjustment Tank (SRAT) cycle using SB2/3 blend slurry.

- Comparison of the SB2/3 blend slurry results with those obtained for the SB3 Qualification. 
WSRC-TR-2004-00097

Revision 0

This page intentionally left blank. 


\subsection{SLUDGE BATCH 2/3 BLEND}

\subsection{Approach}

The SB2/3 blend calculation was based upon the anticipated volume of SB2 remaining in Tank 40 at the time of SB3 addition. High Level Waste Program Development and Integration of the Closure Business Unit projected that the volume of SB2 was expected to be 97" or 263,000 gallons, while the volume of SB3 was expected to be about 131 " or 355,000 gallons. This would give a combined 228 " or 618,000 gallons.

Based upon the above projection and the known densities of a $2003 \mathrm{SB} 2$ sample, $1.14 \mathrm{~g} / \mathrm{mL}^{7}$ and the SB3 Qualification sample, $1.22 \mathrm{~g} / \mathrm{mL}^{8}$ the masses of sludge to combine could be calculated. Two separate blends of $300 \mathrm{~g}$ each were prepared. The first blend was used for rheological measurements and the remainder combined with the second blend for all further characterization measurements and the SRAT cycle experiment.

\subsection{Results}

The measured masses of each sludge sample in the two blend preparations are presented in Table 2-1.

Table 2-1. Mass of Each Sludge Batch and the Final Blend Volume Percent Ratio

\begin{tabular}{cccc}
\hline Blend No. & SB2 $($ g) & SB3 $(\mathbf{g})$ & SB2/3 Vol.\% Ratio \\
\hline 1 & 145.412 & 209.527 & $43 / 57$ \\
2 & 145.436 & 210.250 & $43 / 57$ \\
\hline
\end{tabular}

\subsubsection{Rheological Measurements on SB2/3 Blend}

Rheological measurements were made on Blend 1 to compare the properties with those of the SB3 Qualification sample. The general observation was that the SB2/3 blend was slightly more viscous and visually more cohesive than the SB3 sample. The visual observation is based on how readily the sludge washed off the vane/rotor when using deionized (DI) water. The flow curves shown in Figure 2-1 were very repeatable. For comparison the data from SB3 is shown in Figure 2-2.

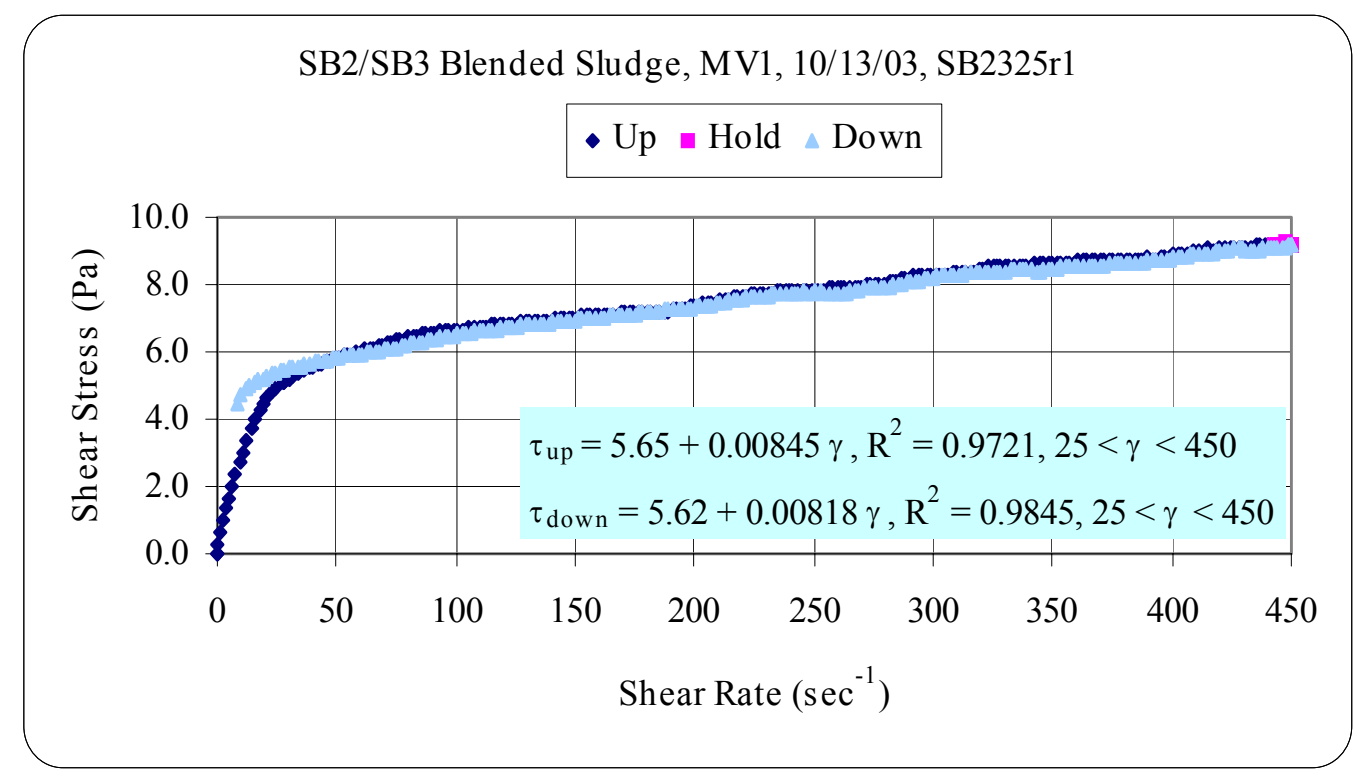


Figure 2-1. SB2/3 Blend Rheogram at $25^{\circ} \mathrm{C}$

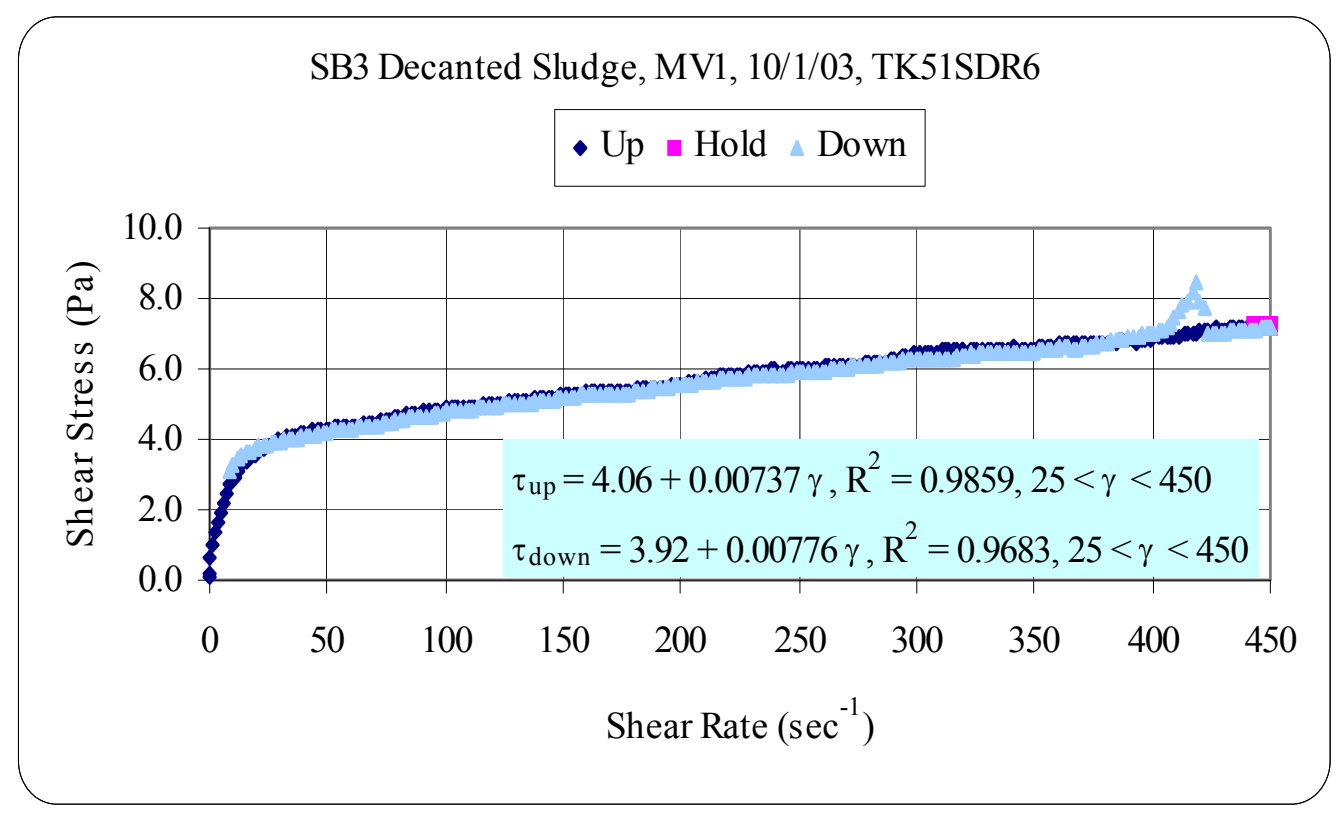

Figure 2-2. SB3 Rheogram at $25^{\circ} \mathrm{C}$

Table 2-2 presents a summary of the rheology results, yield stresses and consistencies, obtained for the 2001 SB2 Qualification sample ${ }^{7}$, the 2003 SB2 sample ${ }^{7}$, the 2003 SB3 Qualification sample ${ }^{1}$, and the SB2/3 blend sample of this report. Available models predict the SB2/3 blend yield stress and consistency would fall intermediate to the individual components that comprise it, but the results obtained indicate the consistency is even more like SB3 alone than would be anticipated.

Table 2-2. Summary of the Rheology Results Obtained from the SB2, SB2/3 Blend, and SB3 Sludge Slurry Samples Compared to the DWPF Operating Region

\begin{tabular}{|c|c|c|c|c|}
\hline Sample & $\begin{array}{c}\text { Total } \\
\text { Solids } \\
(w t . \%) \\
\end{array}$ & $\begin{array}{c}\text { Insoluble } \\
\text { Solids } \\
\text { (wt. \%) } \\
\end{array}$ & $\begin{array}{l}\text { Yield Stress } \\
\left(\text { dynes } / \mathrm{cm}^{2}\right)\end{array}$ & $\begin{array}{c}\text { Consistency } \\
\text { (cp) }\end{array}$ \\
\hline 2001 SB2 Qualification & 18.4 & 15.5 & 119 & 11.1 \\
\hline 2003 SB2 & 19.9 & 17.5 & 166 & 6.0 \\
\hline $\begin{array}{c}2003 \text { SB2 / } \\
\text { SB3 Qualification Blend }\end{array}$ & 22.8 & 16.0 & 56.5 & 8.45 \\
\hline $\begin{array}{l}\text { SB2/3 Blend Olney-Carlson } \\
\text { Prediction }\end{array}$ & NA & NA & 58.3 & 12.4 \\
\hline $\begin{array}{l}\text { SB2/3 Blend Kendall- } \\
\text { Monroe Prediction }\end{array}$ & NA & NA & 60.1 & 13.2 \\
\hline SB3 Qualification & 29.9 & 15.4 & 40.6 & 7.37 \\
\hline DWPF Operating Region ${ }^{9,10}$ & $13-19 \dagger$ & NA & $25-100$ & $4-12$ \\
\hline
\end{tabular}


Figure 2-3 provides up-curves for two models, the Olney-Carlson ${ }^{11}$ and the Kendall-Monroe ${ }^{12}$ predictions. Figure 2-4 provides the Bingham plastic yield stress $(\mathrm{Pa})$ and consistency $(\mathrm{Pa}-\mathrm{sec})$ for the model predictions.

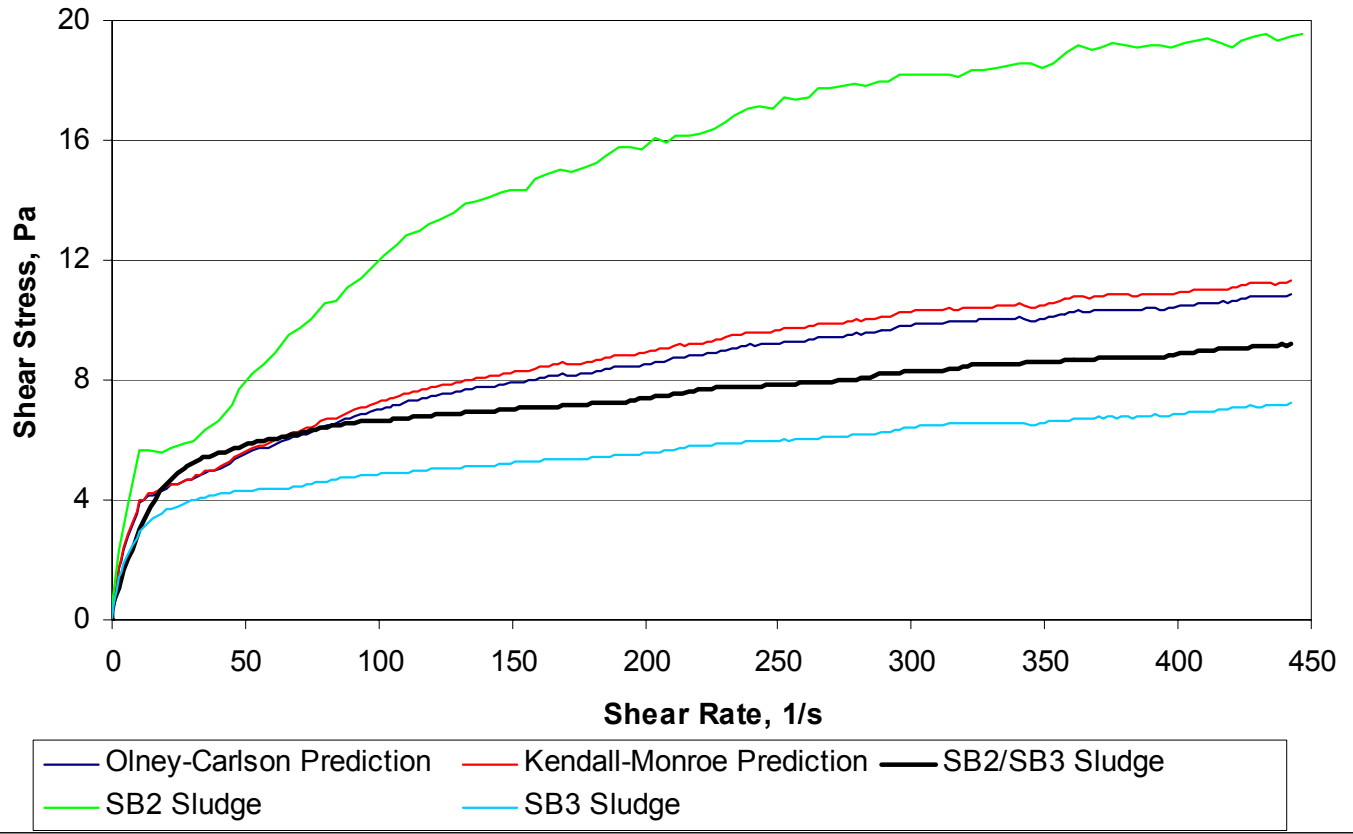

Figure 2-3. Model Predictions of Rheological Behavior for SB2/3 Blend (Up-Curves)

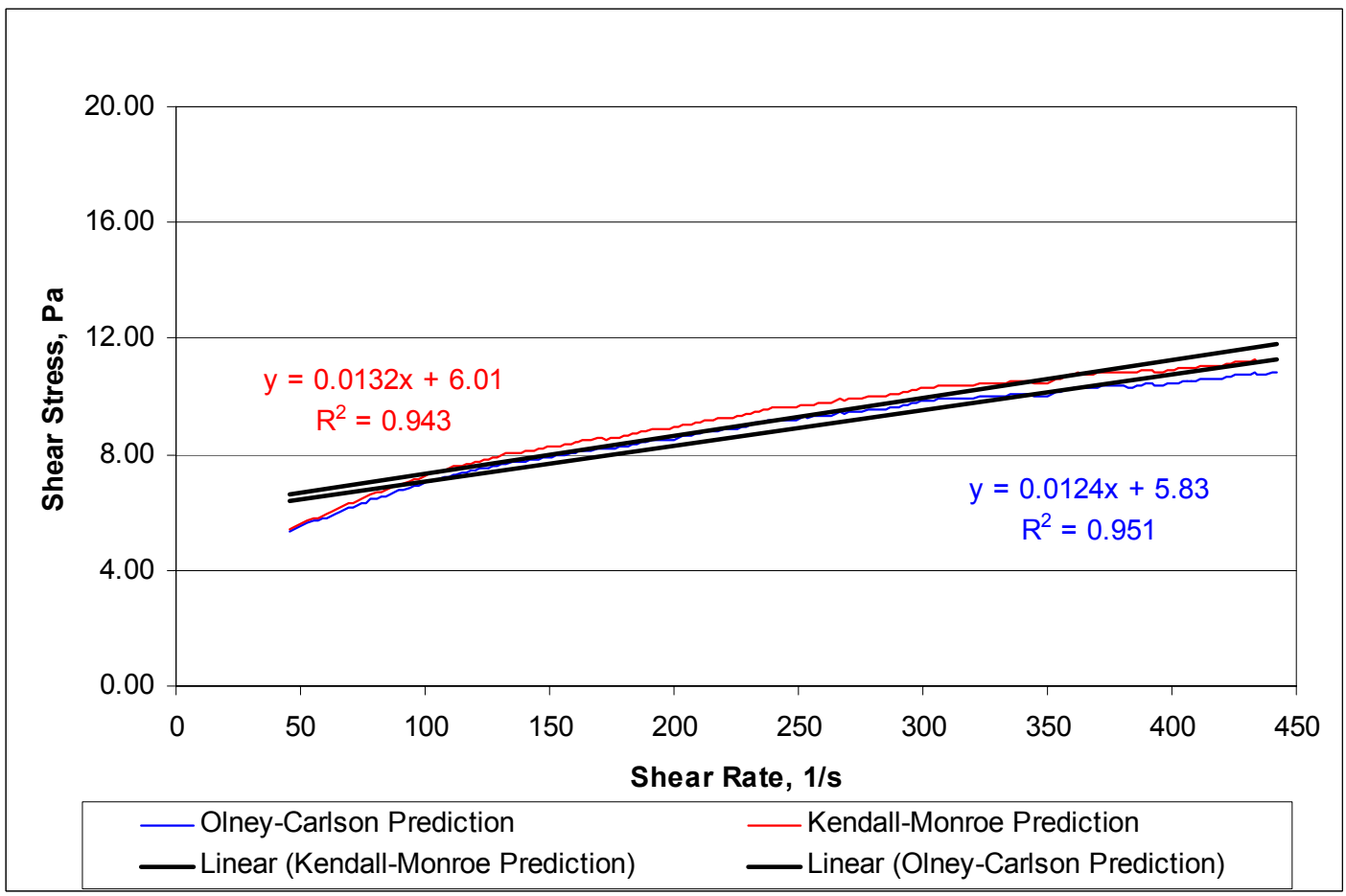

Figure 2-4. Blending Model Up-Curve Fits for a Bingham Plastic 


\subsubsection{Surface Tension Measurements}

The surface tension of the SB2/3 blend supernate was measured at $23^{\circ} \mathrm{C}$. The surface tension measurement was made using a fine, calibrated capillary tube designed for these measurements. The following formula was used to calculate the surface tension (T) from the measured height of the liquid column:

Where:

$$
\mathrm{T}=\mathrm{rhdg} / 2
$$

$$
\begin{aligned}
& \mathrm{r} \equiv \operatorname{radius}(\mathrm{cm}) \\
& \mathrm{h} \equiv \text { height of the liquid column }(\mathrm{cm}) \\
& \mathrm{d} \equiv \operatorname{density~}(\mathrm{g} / \mathrm{mL}) \\
& \mathrm{g} \equiv \operatorname{gravitational~constant}\left(980.7 \mathrm{~cm} / \mathrm{s}^{2}\right)
\end{aligned}
$$

The calculated tension value and a comparison to other measured and known values are given in Table 2-3. All the measurements were made at ambient temperature and since the density varies only slightly with temperature, the results are comparible. As one can see the SB2/3 blend supernate has a surface tension close to that of water and significantly higher than either under-washed or over-washed SB2 simulants.

Table 2-3. Surface Tension of Various Materials

\begin{tabular}{cc}
\hline Material & Surface Tension (dynes/cm) \\
\hline SB2/3 Blend & 68.9 \\
SB2 Simulant (under-washed) & 60.1 \\
SB2 Simulant (over-washed) & 61.8 \\
$\mathrm{H}_{2} \mathrm{O} @ 25^{\circ} \mathrm{C}$ & 71.9 \\
$\mathrm{H}_{2} \mathrm{O}$ (measured) & 70.9 \\
\hline
\end{tabular}

\subsubsection{SRAT Cycle Feed Characterization}

A number of physical and chemical characterizations were performed on the SB2/3 blend in order to

\begin{tabular}{|c|c|}
\hline Weight Percent and Density & $\begin{array}{c}\text { Average } \\
\text { (Std. Dev., \% RSD) }\end{array}$ \\
\hline Total Solids (wt. \% of slurry) ${ }^{\mathrm{a}}$ & $22.8(1.4,6.1)$ \\
\hline Dissolved (Uncorrected Soluble) Solids (wt. \% of supernate) ${ }^{\mathrm{a}}$ & $8.06(0.08,0.98)$ \\
\hline Soluble Solids (wt. \% of slurry) ${ }^{b}$ & $6.77(\mathrm{NA})$ \\
\hline Insoluble Solids (wt. $\%$ of slurry) ${ }^{\mathrm{c}}$ & 16.0 (NA) \\
\hline Slurry Density (g/mL) & $1.15(0.01,1.0)$ \\
\hline Supernate Density $(\mathrm{g} / \mathrm{mL})$ & 1.06 \\
\hline
\end{tabular}
compare it to the SRNL SB3 Qualification sample, SB3 simulants, and to provide the necessary input data for the acid addition calculations needed for a SRAT cycle. The density and weight percent solids measurements are summarized in Table 2-4.

Table 2-4. Weight Percent Solids and Density of the SB2/3 Blend Sample 
Values for the major anions of interest, including formate, nitrite, nitrate, and total inorganic carbon (TIC), are given in Table 2-5. The oxalate value in this table was determined by the acid strike method developed in the Analytical Development Section (ADS). Due to the significantly lower nitrite, nitrate, oxalate, sulfate, and TIC content, as well as the base equivalents to $\mathrm{pH} 7$, in SB2 relative to SB3, the blend had decidedly lower values for these species than the recent SB3 Qualification sample. See Table 2-6. Both samples were processed under the same excess acid levels in order to make comparisons of the two SRAT cycles possible. However, the redox targets were different. Section 3.0 of this report will look at the details of the completed SRAT cycle and the inputs used in the acid calculations.

Table 2-5. Anions, Base Equivalents, $\mathrm{pH}$ and TIC Results in the SB2/3 Blend

\begin{tabular}{cc}
\hline Anion & Average (Std. Dev., \%RSD) \\
\hline Formate (mg/kg slurry) & $69(2.7,4.0)$ \\
Nitrite (mg/kg slurry) & $18,500(390,2)$ \\
Nitrate (mg/kg slurry) & $12,000(260,2)$ \\
Oxalate (mg/kg slurry) & $919(141,15)$ \\
Sulfate (mg/kg slurry) & $2340(360,16)$ \\
TIC (mg/kg slurry) & $991(53,5.3)$ \\
$\mathrm{pH}$ & $13.04(0.11,0.8)$ \\
Base Equivalents (Eq./L) & 0.459 \\
\hline
\end{tabular}

Table 2-6. Comparison of Selected Measured Properties of SB2 (2003), SB3 Qualification, and $\mathrm{SB} 2 / 3$ Blend Samples (mg/kg slurry)

\begin{tabular}{|c|c|c|c|c|c|c|c|}
\hline & Formate & Nitrite & Nitrate & Oxalate & Sulfate & TIC & $\begin{array}{c}\text { Base Equiv. } \\
\text { (Eq./L) }\end{array}$ \\
\hline SB2 $(2003)^{13}$ & $20 \ddagger$ & 5590 & 2980 & $380 \ddagger$ & $840+$ & 879 & 0.276 \\
\hline SB2/3 Blend & 69 & 18,500 & 12,000 & 919 & 2340 & 991 & 0.459 \\
\hline SB3 Qual. ${ }^{19}$ & $<400$ & 25,300 & 19,600 & $1590 \dagger$ & 3540 & 1260 & 0.577 \\
\hline
\end{tabular}

Table 2-7 gives the elemental composition of the SB2/3 blend in terms of wt. $\%$ of total air dried solids. The values measured were similar to those predicted based upon the 2003 SB2 sample and the SB3 Qualification sample. These predicted values, as well as the difference between the measured and predicted values, where possible, are provided in Table 2-7. The predicted values are based on a weighted average of the total solids content of each element in the blend. The large difference in the predicted and measured values for $\mathrm{Cu}$ is most likely due to analytical uncertainty when measuring small quantities. The low measured Si value may be a result of incomplete dissolution during the aqua regia digestion of the sample. The elemental data from the peroxide fusion preparations are not reported since the standards did not have acceptable recoveries. For the major species the predicted and measured values are within 10-20\% of each other, reflecting the combined errors in the measurement of these elements for both the 2003 SB2 and SB3 Qualification samples. 
Table 2-7. Elements in the SB $2 / 3$ Blend SRAT Cycle Feed

\begin{tabular}{cccc}
\hline Element & $\begin{array}{c}\text { Wt. \% of Total Solids } \\
\text { (Std. Dev., \%Rel. Std. Dev.) }\end{array}$ & $\begin{array}{c}\text { Wt. \% of Total Solids } \\
\text { Predicted }\end{array}$ & $\begin{array}{c}\text { Difference from } \\
\text { Prediction (\%) }\end{array}$ \\
\hline $\mathrm{Al}$ & $5.91(0.40,6.7)$ & 5.23 & 13 \\
$\mathrm{~B}$ & $<0.018(\mathrm{NA})$ & - & - \\
$\mathrm{Ba}$ & $0.057(0.004,6.5)$ & 0.044 & 30 \\
$\mathrm{Be}$ & $<0.001(\mathrm{NA})$ & - & - \\
$\mathrm{Ca}$ & $1.83(0.12,6.4)$ & 1.62 & 13 \\
$\mathrm{Cd}$ & $0.205(0.014,7.0)$ & 0.183 & 12 \\
$\mathrm{Cr}$ & $0.117(0.009,7.8)$ & 0.099 & 18 \\
$\mathrm{Cu}$ & $0.027(0.002,6.8)$ & 0.092 & -71 \\
$\mathrm{Fe}$ & $19.7(1.3,6.8)$ & 17.2 & 15 \\
$\mathrm{~K}$ & $<0.4(\mathrm{NA})$ & 0.042 & $\mathrm{NA}$ \\
$\mathrm{Mg}$ & $1.84(0.13,6.9)$ & 1.61 & 16 \\
$\mathrm{Mn}$ & $4.32(0.30,6.9)$ & 3.71 & 13 \\
$\mathrm{Na}$ & $13.2(0.9,6.5)$ & 11.6 & -7 \\
$\mathrm{Ni}$ & $1.16(0.08,7.3)$ & 1.25 & - \\
$\mathrm{P}$ & $0.472(0.018,3.8)$ & - & $\mathrm{NA}$ \\
$\mathrm{Pb}$ & $<0.080(\mathrm{NA})$ & 0.039 & - \\
$\mathrm{Sb}$ & $0.069(0.005,6.5)$ & - & -65 \\
$\mathrm{Si}$ & $0.317(0.029,9.2)$ & 0.901 & - \\
$\mathrm{Ti}$ & $0.020(0.002,7.6)$ & - & 11 \\
$\mathrm{U}$ & $7.22(0.51,7.0)$ & 6.52 & \\
\hline
\end{tabular}

${ }^{\mathrm{a}}$ Average of four measurements by ICP-ES (from aqua regia digestions). 


\subsection{SRAT CYCLE}

\subsection{Approach}

\subsubsection{Equipment Set-Up}

The vessel used in the SB2/3 SRAT cycle was a glass cylinder approximately 6.75 inches in height and 3.5-3.825 inches in diameter. The vessel had a capacity of approximately one liter. The top of the vessel consisted of a glass lid fitted with a set of ports. These ports were for the installation of supporting equipment, e.g. agitator, thermocouple, and manometer. The ports also provided access for process lines, e.g. the primary off-gas line from the SRAT condenser, the air purge inlet, the formic and nitric acid addition lines, and the antifoam addition line. See Figure 3-1 for a photograph of the vessel in the SRNL Shielded Cells Mockup area.

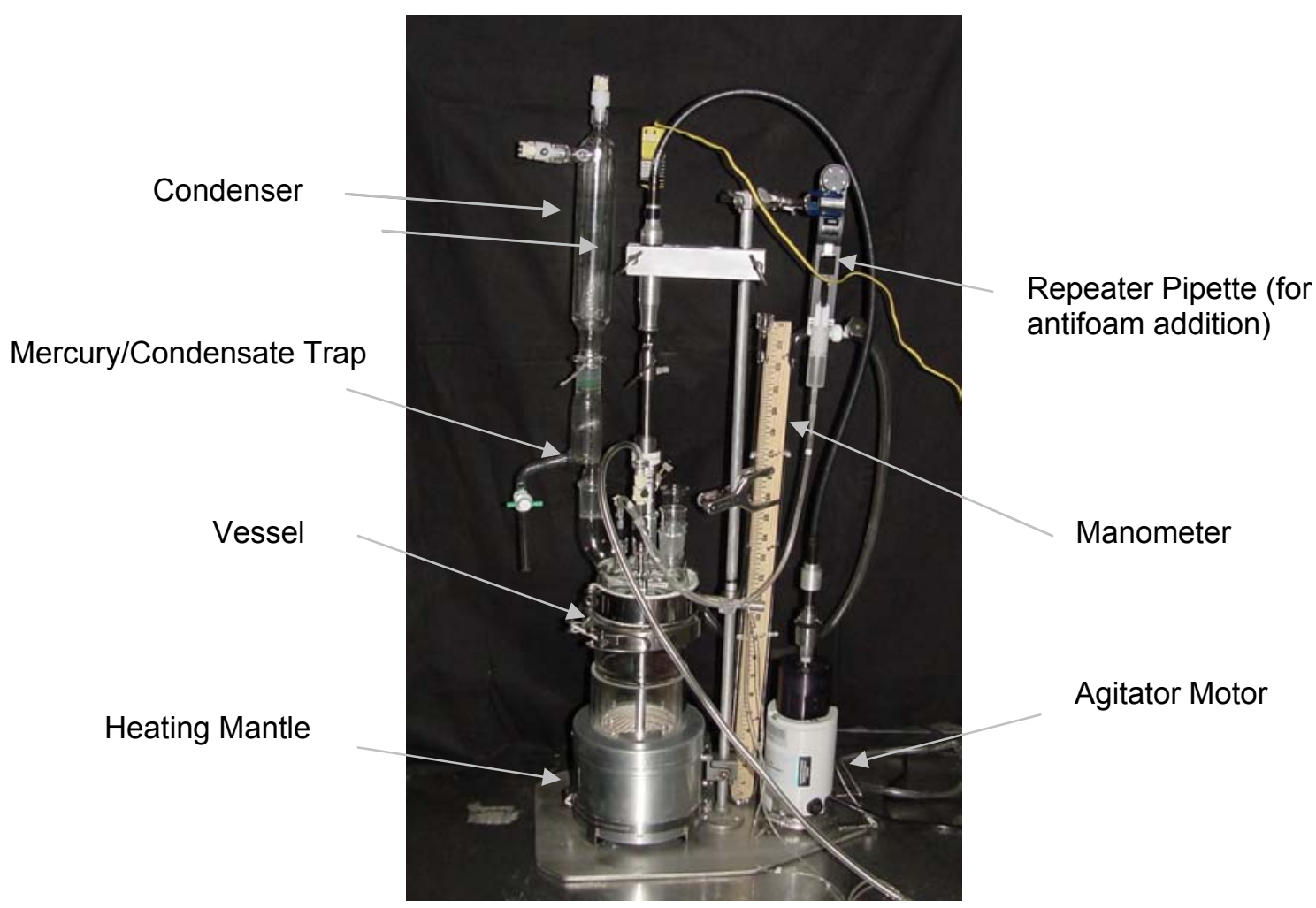

Figure 3-1. Photograph of 1-L SRAT Vessel in SRNL Shielded Cells Mockup Area

Peripheral equipment was required to perform the SRAT cycle. This included a SRAT condenser and decanter. The condenser was cooled using chilled water at $10^{\circ} \mathrm{C}$ supplied within the Cells by a MasterFlex recirculation pump. SRAT condenser condensate was collected in a mercury/condensate decanter. Aqueous-phase condensate could either be removed during the concentration step (dewatering), or it could be allowed to siphon back to the SRAT. Any coalesced elemental mercury would be retained in the decanter. 
The heat source to the SRAT was an electric heating mantle that covered the lower two inches $(180 \mathrm{~mL})$ of the vessel. The mantle was controlled by a multipurpose DigiTrol II controller connected to the SRAT thermocouple. This controller was used for both temperature set-point control, e.g. during acid addition at $93^{\circ} \mathrm{C}$, and for boil-up rate control, i.e., achieving the bench-scale equivalent to a DWPF-scale $5,000 \mathrm{lbs} / \mathrm{hr}$ boil-up rate.

The agitator was variable speed and consisted of one flat blade turbine impeller. The agitator was driven by a Stir-Pak mixer head attached to a mixing controller. The speed was adjusted until a small vortex was visible on the surface of the slurry.

Acid addition was made using a MasterFlex cartridge pump. Separate pump cartridges were used for the nitric acid and formic acid lines. A variable speed controller was used to adjust the flow rate to achieve the equivalent of two gallons/min. in DWPF.

Air was supplied for purging the SRAT vessel from a compressed gas cylinder containing air mixed with 0.46 vol.\% helium. The flow rate was adjusted and controlled with a MKS flow controller. A DWPF scaled SRAT purge flow was used during the test. The DWPF purge rate is $230 \mathrm{cfm}^{\mathrm{a}}$. The air purge passed through the SRAT vessel and became the carrier for the off-gas flow. Following the SRAT condenser, it passed through a dry ice trap to remove residual moisture. A U-tube manometer was mounted to the SRAT vessel head space to monitor pressure in the vessel.

A portion of the off-gas stream was pulled into a Varian CP-2002 Micro Gas Chromatograph (GC) for sampling. Column A contains a Molsieve 5A column. It measures helium, hydrogen, oxygen, and nitrogen. Column B contains a PoraPlot Q column. It measures carbon dioxide and nitrous oxide. The GC is located in a radiohood located behind the Shielded Cells. Calibration gas is kept near the radiohood, and was used to calibrate the peak areas prior to the SRAT cycle. It was also used to check the calibrations following the cycle.

\subsubsection{Acid Calculations for the SRAT Cycle}

Analytical data from Section 2.0, along with data presented in this section, were entered into the Immobilization Technology Section's (ITS) acid addition calculation spreadsheet. The ITS spreadsheet differs from the DWPF spreadsheet in that it does not factor in a heel. The total acid requirement was determined. This was then divided into nitric acid and formic acid using projected anion reaction outcomes and an iron in glass redox target of $0.20 \mathrm{Fe}^{+2} / \Sigma \mathrm{Fe}$.

Samples of the nitric and formic acids used in this experiment were submitted for analyses by titration against a reference base. The average result of this analysis for nitric acid was $10.28 \mathrm{M}$ (49.6 wt. \%). The specific gravity for nitric acid at this molarity and $20^{\circ} \mathrm{C}$ is 1.307 . The average result of this analysis for formic acid was $22.40 \mathrm{M}\left(86.1 \mathrm{wt}\right.$. \%). The specific gravity for formic acid at this molarity and $20^{\circ} \mathrm{C}$ is 1.198 .

The recommended target for acid in the Shielded Cells SB2/3 SRAT cycle was $140 \%$ of the calculated stoichiometric requirement ${ }^{14}$. This recommendation was based on nonradioactive simulant testing ${ }^{15}$ including Actinide Removal Process (ARP) testing and Slurry-Fed Melt Rate Furnace runs with SB2/3 simulant, and the value selected for the SB3 Qualification SRAT cycle. The stoichiometric acid calculation was the same as that currently being used in DWPF (function of total equivalent base, inorganic carbon, nitrite, manganese, and mercury in the vessel). The redox equation developed and

${ }^{\mathrm{a}}$ DWPF purge rates are referenced to $70^{\circ} \mathrm{F}$ and 1 atmosphere. 
recommended for SB3 processing instead of the $\mathrm{F}-3 \mathrm{~N}$ equation was used. The new redox equation was described in WSRC-TR-2003-00126 (C.M. Jantzen et al.) ${ }^{16}$. It is given by:

$$
\frac{F e^{+2}}{\Sigma F e}=0.1942+0.191 *(2 * F+2 * O+4 * \operatorname{Coal}-5 *(N 1+N 2)-2 * M n) * \frac{45 \%}{w t . \% T S}
$$

Where:

$\mathrm{F} \quad$ formate in SME product, $\mathrm{g}-\mathrm{mole} / \mathrm{kg}$ SME product

$\mathrm{O} \quad$ oxalate in SME product, g-mole/kg SME product

$\mathrm{C} \quad$ coal in SME product, g-mole/kg SME product

N1 nitrate in SME product, g-mole/kg SME product

N2 nitrite in SME product, g-mole/kg SME product

Mn total manganese in SME product, g-mole/kg SME product

wt. $\%$ TS $\quad$ wt. $\%$ total solids of SME product slurry

A simulant test at $155.5 \%$ of stoichiometry was successful in meeting the processing objectives for SB3, while a second test at $127.9 \%$ met all processing objectives except for nitrite destruction. An assessment of the sensitivity of the delivered acid to the various measurements that form the Shielded Cells acid calculation is available ${ }^{17}$. This indicated that a $\sim 9 \%$ error in acid delivery relative to the target occurs about $5 \%$ of the time. Therefore a target at $91 \%$ of $155.5 \%$, or $141 \%$, was recommended for the Shielded Cells qualification run with SB3. This was believed to be sufficiently conservative to ensure that hydrogen generation would remain within the DWPF design basis limit while offering a reasonable chance to obtain nitrite levels below the DWPF detection limit of approximately $1000 \mathrm{mg} / \mathrm{kg}$ in the SRAT product.

At the time of the acid calculation for this experiment, a new method of acid standardization was under evaluation at the Aiken County Technical Laboratory (ACTL). The new method utilizes a density meter, model DMA-4500, to automatically calculate the weight percent formic acid, nitric acid, hydrochloric acid or sodium hydroxide. Based upon testing with this instrument, the formic acid used in this SRAT process could have been as high as $90 \mathrm{wt} \%$. This would place the acid stoichiometry at $147 \%$ instead of $140 \%$ and the predicted glass redox at 0.221 rather than 0.2 .

The following additional assumptions were recommended based on SB2/3 simulant testing ${ }^{18}$ :

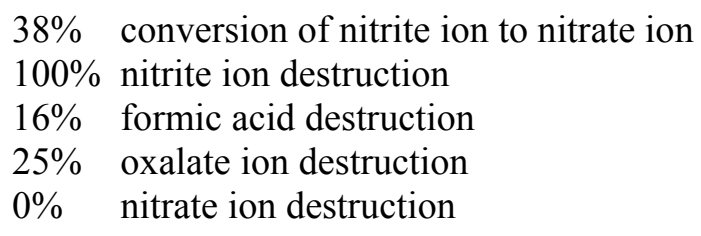

The acid calculation at $140 \%$ stoichiometry led to an acid requirement of 1.7 moles acid per liter of starting sludge (see Table 3-1). This compares with 2.3 moles acid per liter of starting sludge for the SB3 Qualification sample. SB2 was qualified with only 0.94 moles acid per liter of starting sludge. The increased acid requirement for SB3 was driven by two known causes. The base equivalents more than doubled from SB2, and the nitrite ion concentration more than tripled from SB2. Table 3-1 summarizes the input to and output from the SB2/3 SRAT cycle acid calculation along with those for the 2003 SB2 sample and the SB3 Qualification sample. 
Table 3-2. DWPF and SRNL Scale SRAT Processing Parameters and Acid Addition Amounts

\begin{tabular}{ccc}
\hline Parameter & DWPF Scale & SRNL Scale \\
\hline SRAT Contents & $6,000 \mathrm{gal}$ & $0.253 \mathrm{~L}$ \\
Gas Purge Rate & $230 \mathrm{scfm}$ & $79 \mathrm{sccm}$ \\
Acid Addition Rate & $2 \mathrm{gal} / \mathrm{min}$ & $0.09 \mathrm{~mL} / \mathrm{min}$ \\
Boil Up Rate & $5,000 \mathrm{pounds} / \mathrm{hr}$ & $28 \mathrm{~g} / \mathrm{hr}$ \\
Acid Stoichiometry & $140 \%$ & $140 \%$ \\
Nitric Acid & $29.1 \mathrm{gal}$ & $1.34 \mathrm{~mL}$ \\
Formic Acid & $413.9 \mathrm{gal}$ & $19.07 \mathrm{~mL}$ \\
\hline
\end{tabular}

\subsection{Results}

The SRAT cycle was completed per the run plan including acid addition times. No additional antifoam was added after the initiation of boiling, since there were no bubbles or foaming observed in the system. At the end of the cycle nitrite was destroyed and the DWPF hydrogen generation rate was not exceeded.

\subsubsection{SRAT Cycle Product Characterization}

The following tables summarize the solids, density, $\mathrm{pH}$, anion, and elemental composition of the SRAT cycle product produced from the SB2/3 blend. The SB2/3 blend SRAT product solids are similar to those found for the SB3 Qualification sample SRAT product [Total: 29.9, Dissolved: 17.2, Soluble: 14.6, Insoluble: 15.4$]^{1}$, though the insoluble solids are lower. The final $\mathrm{pH}$ of the $\mathrm{SB} 2 / 3$ blend is also higher as compared to that found during qualification of SB3 [pH 5.2].

Table 3-3. Weight Percent Solids, Density, and Final pH of the SRAT Cycle Product Using the SB2/3 Blend Sample

\begin{tabular}{lcc}
\hline \multicolumn{1}{c}{ Weight Percent and Density } & $\begin{array}{c}\text { SB2/3 Blend } \\
\text { (Std. Dev., \%RSD) }\end{array}$ & $\begin{array}{c}\text { SB3 Qualification } \\
\text { (Std. Dev., \%RSD) }^{\text {\% }}\end{array}$ \\
\hline Total Solids (wt. \% of slurry) $^{\mathrm{a}}$ & $27.3(0.12,0.5)$ & $29.9(0.05,0.2)$ \\
$\begin{array}{l}\text { Dissolved (Uncorrected Soluble) Solids } \\
\text { (wt. \% of supernate) }^{\mathrm{a}}\end{array}$ & $17.6(1.02,5.8)$ & $17.2(0.04,0.2)$ \\
Soluble Solids (wt. \% of slurry) & & \\
Insoluble Solids (wt. \% of slurry) $^{\mathrm{c}}$ & $15.5(\mathrm{NA})$ & $14.6(0.05,0.3)$ \\
Slurry Density (g/mL) & $11.8(\mathrm{NA})$ & $15.4(0.09,0.6)$ \\
Supernate Density $(\mathrm{g} / \mathrm{mL})$ & $1.25(0.020,1.6)$ & $1.27(0.004,0.3)$ \\
pH & $1.11(0.005,0.4)$ & $1.14(0.008,0.7)$ \\
\hline${ }^{\mathrm{a}}$ Measured. & 5.63 & 5.2 \\
${ }^{\mathrm{b}}$ Calculated from wt. \% total and insoluble solids & & \\
${ }^{\mathrm{c}}$ Calculated from wt. \% total and dissolved solids & &
\end{tabular}

Anion measurements were made from three sample preparation methods. The first looked at a water dilution of the SRAT product supernate. The second looked at a water dilution of the slurry while the third looked at a slurry sample struck with $2 \mathrm{~mL}$ each of concentrated nitric acid and concentrated hydrochloric acid prior to dilution. These methods were suggested at the time because of the ongoing investigation into the measurement of sulfur in SRAT feeds and products. Based upon a comparison of the oxalate data in Table 3-4, it would appear that the acid struck slurry oxalate value is likely low, 
probably as a result of light catalyzed oxidation in the presence of acid and manganese. The standards in all cases gave reasonable recoveries. The sulfate values are essentially equivalent within uncertainties between the supernate and slurry measurements (whether or not the slurry was struck with acid) indicating the available sulfate measured was in fact all soluble. For further information on sulfur analyses the reader is referred to WSRC-TR-2004-00092.

Table 3-4. Measured Ion Chromatography Anions in the SB2/3 Blend SRAT Product

\begin{tabular}{cccc}
\hline Anion & $\begin{array}{c}\text { Supernate } \\
\text { Concentration in } \\
\text { mg/kg slurry } \\
\text { (Std. Dev., \%RSD) }\end{array}$ & $\begin{array}{c}\text { Slurry } \\
\text { Concentration in } \\
\text { mg/kg slurry } \\
\text { (Std. Dev., \%RSD) }\end{array}$ & $\begin{array}{c}\text { Slurry (acid struck) } \\
\text { Concentration in } \\
\text { mg/kg slurry } \\
\text { (Std. Dev., \%RSD) }\end{array}$ \\
\hline Fluoride & $<30$ (NA) & $<180(\mathrm{NA})$ & - \\
Formate & $54,700(1800,3.3)$ & $51,600(2100,4.0)$ & - \\
Chloride & $<30(\mathrm{NA})$ & $<180(\mathrm{NA})$ & - \\
Nitrite & $<170(\mathrm{NA})$ & $<900(\mathrm{NA})$ & - \\
Nitrate & $29,100(1000,3.5)$ & $28,200(1300,4.4)$ & - \\
Phosphate & $<170(\mathrm{NA})$ & $<900(\mathrm{NA})$ & $2500(400,15)$ \\
Sulfate & $2500(110,4.4)$ & $2300(120,5,2)$ & $500(200,40)^{*}$ \\
Oxalate & $970(56,5.8)$ & $1100(24,2.2)$ & - \\
Bromide & $<170(\mathrm{NA})$ & $<900(\mathrm{NA})$ & \\
\hline
\end{tabular}

* See previous text for further explanation

Elemental samples were prepared analogous to those for anion measurements described above and are shown in Table 3-5 on mg of element per kg of slurry basis. All measurements were made in triplicate and averaged. In all cases the acid struck slurry samples had the highest measured values. Note that SRAT product solids were not digested and analyzed separately to reduce analytical expenses. The differences seen between the water diluted slurry and the supernate samples are most interesting. At first thought one would think these two values would be nearly equivalent, but in some cases the water diluted slurry value is higher (e.g. Si) than the supernate value, and in other cases the supernate value is higher than the water struck slurry value (e.g. U). In the case of uranium, it would seem some initially soluble uranium may have precipitated upon dilution of the slurry and been removed when the sample was filtered prior to analysis. In the absence of solids this precipitation may not have occurred. For silica the situation is reversed. Some initially insoluble silica species may have dissolved upon dilution.

High levels of soluble uranium were also found in the SB3 Qualification SRAT product ${ }^{1}$ and initially attributed to the plutonium and neptunium streams added to the waste. It turns out that the vast majority of this freshly precipitated uranium comes from the $\mathrm{Am} / \mathrm{Cm}$ stream added to Tank 51 prior to sampling for qualification ${ }^{21}$; roughly $9 \%$ of the total uranium in SB3. While it is possible that the uranium is in a less crystalline form and more readily soluble at the SRAT product $\mathrm{pH}$ of 5.6 (5.2 for SB3 Qualification sample SRAT product) than other forms of uranium common to SB2 that have aged in the tank farm waste for years, calculations indicated that there is not enough freshly precipitated uranium in these combined streams to account for the level of soluble uranium observed in either of these SRAT cycles (67\% for SB3 SRAT Product and 50\% for SB2/3 SRAT Product). Previous SB2 work $^{7,13}$ resulted in SRAT product of higher ending $\mathrm{pH}, 6.8$ and 6.2. In the latter SRAT cycle, the $\mathrm{pH}$ was lowered to the original target of 5.5 after the SRAT cycle was complete; there was no reflux at the adjusted pH level. Unfortunately, no elemental analyses were performed on the adjusted supernate (lower $\mathrm{pH}$ ) so the soluble uranium level at $\mathrm{pH} 5.5$ is unknown. The soluble uranium values for the original SB2 SRAT products at $\mathrm{pH} 6.8$ and $\mathrm{pH} 6.2$ were recently measured and determined to be $48.6 \mathrm{mg} / \mathrm{kg}$ slurry and 44.5 $\mathrm{mg} / \mathrm{kg}$ slurry, respectively. This corresponds to $0.060 \%$ and $0.055 \%$ of the total uranium content of the 
starting sludge. These values are a fraction of those observed in either this report on blended SB2/3 or the SB3 qualification SRAT products.

Based upon the hydrolysis constant for uranyl ion of $\log \mathrm{K}_{\mathrm{H}}=-5.9^{22}$ at $I=3 \mathrm{M}$, i.e. the tendency for $\mathrm{UO}_{2}{ }^{2+}$ to extract a hydroxyl ion from water at a given temperature and ionic strength, the concentration of hydrolyzed uranyl ion and unhydrolyzed uranyl ion at $\mathrm{pH} 6$ would be essentially equal. In other words, the $\left[\mathrm{UO}_{2}(\mathrm{OH})^{+}\right]$is equal to the $\left[\mathrm{UO}_{2}{ }^{2+}\right]$. Generally when one reaches the $\mathrm{pH}$ at which a metal ion species is in equilibrium with its first hydrolysis species, there will already be the beginning of metal ion precipitation occurring, in this case $\mathrm{UO}_{2}(\mathrm{OH})_{2}$. There are many differences between an ideal solution at $25{ }^{\circ} \mathrm{C}$ and $I=3 \mathrm{M}$ and SRAT product with its variety of metal ion equilibria and potential complexing anions, but there does appear to be a threshold $\mathrm{pH}$ of around 6 when the soluble uranium level begins to increase significantly. This is consistent with the observations sited here and yet unpublished observations from the study of uranium in SB2 simulant. Therefore, it seems reasonable that the final $\mathrm{pH}$ of the SRAT product is the contributing factor to the level of soluble uranium measured.

Table 3-5. Elements in the SB2/3 Blend SRAT Product

\begin{tabular}{cccc}
\hline Element & $\begin{array}{c}\text { Supernate } \\
\text { Concentration in } \\
\text { mg/kg slurry } \\
\text { (Std. Dev., \%RSD) }\end{array}$ & $\begin{array}{c}\text { Slurry (acid struck) } \\
\text { Concentration in } \\
\text { mg/kg slurry } \\
\text { (Std. Dev., \%RSD) }\end{array}$ & $\begin{array}{c}\text { Slurry (water struck) } \\
\text { Concentration in } \\
\text { mg/kg slurry } \\
\text { (Std. Dev., \%RSD) }\end{array}$ \\
\hline $\mathrm{Al}$ & $<21(\mathrm{NA})$ & $5260(60,1.1)$ & $<110(\mathrm{NA})$ \\
$\mathrm{B}$ & $<11(\mathrm{NA})$ & $133(33,25)$ & $<58.5(\mathrm{NA})$ \\
$\mathrm{Ca}$ & $2030(20,1.0)$ & $3870(10,0.3)$ & $2170(66,3.1)$ \\
$\mathrm{Cr}$ & $<7(\mathrm{NA})$ & $157(4.8,3.0)$ & $<35(\mathrm{NA})$ \\
$\mathrm{Cu}$ & $5.7(0.2,4.1)$ & $26.1(0.8,3.0)$ & $<8.9(\mathrm{NA})$ \\
$\mathrm{Fe}$ & $2.8(0.4,16)$ & $11,300(190,1.7)$ & $<7.1(\mathrm{NA})$ \\
$\mathrm{K}$ & $<190(\mathrm{NA})$ & $<880(\mathrm{NA})$ & $<2.7(\mathrm{NA})$ \\
$\mathrm{Li}$ & $5.7(0.4,7.2)$ & $33.3(3.2,9.6)$ & $3210(45,1.4)$ \\
$\mathrm{Mg}$ & $3170(31,1.0)$ & $3750(30,0.8)$ & $3660(28,0.8)$ \\
$\mathrm{Mn}$ & $3700(36,1.0)$ & $7810(94,1.2)$ & $29,300(780,2.6)$ \\
$\mathrm{Na}$ & $28,500(380,1.3)$ & $30,500(430,1.4)$ & $<48(\mathrm{NA})$ \\
$\mathrm{Ni}$ & $43.0(1.2,2.8)$ & $1080(21,2.0)$ & $540(11,2.0)$ \\
$\mathrm{Si}$ & $69.4(1.6,2.3)$ & $2300(81,3.5)$ & $<12(\mathrm{NA})$ \\
$\mathrm{Ti}$ & $3.84(0.03,0.9)$ & $26.5(1.4,5.3)$ & $3820(640,17)$ \\
$\mathrm{U}$ & $8190(86,1.1)$ & $15,030(230,1.5)$ & $<12(\mathrm{NA})$ \\
$\mathrm{Zr}$ & $<2.7(\mathrm{NA})$ & $<14(\mathrm{NA})$ & \\
\hline
\end{tabular}

\subsubsection{Off-Gas Generation}

Maximum DWPF scale gas generation rates observed during the run are presented in Table 3-6. The gas generation rates are below those measured during the SB3 Qualification SRAT cycle reflecting the reduced levels of formic acid, noble metals, nitrite, and TIC in the blend. 
Table 3-6. Maximum Observed DWPF Scale Hydrogen, Carbon Dioxide, and Nitrous Oxide Concentrations and Generation Rates During the SB2/3 SRAT Cycle in the SRNL Shielded Cells

\begin{tabular}{ccc}
\hline Gas & $\begin{array}{c}\text { Maximum } \\
\text { Observed } \\
\text { Volume \% }\end{array}$ & $\begin{array}{c}\text { Maximum Gas } \\
\text { Generation } \\
\text { Rate }(\mathbf{l b} / \mathbf{h r})\end{array}$ \\
Hydrogen & 0.015 & 0.011 \\
Carbon Dioxide & 16 & 290 \\
Nitrous Oxide & 4.4 & 89 \\
\hline
\end{tabular}

Figure 3-2 shows a plot of carbon dioxide, nitrous oxide and hydrogen generation rates on a DWPF scale relative to the completion of acid addition. Based on this diagram, the SRAT cycle behaved as expected. Carbon dioxide evolved during and immediately after acid addition, indicating destruction of carbonate and some destruction of formic acid. Nitrous oxide evolved during and after acid addition, indicating nitrite destruction. Hydrogen generation began increasing after acid addition but after nitrous oxide generation dropped significantly, giving an indication of the completion of nitrite destruction.

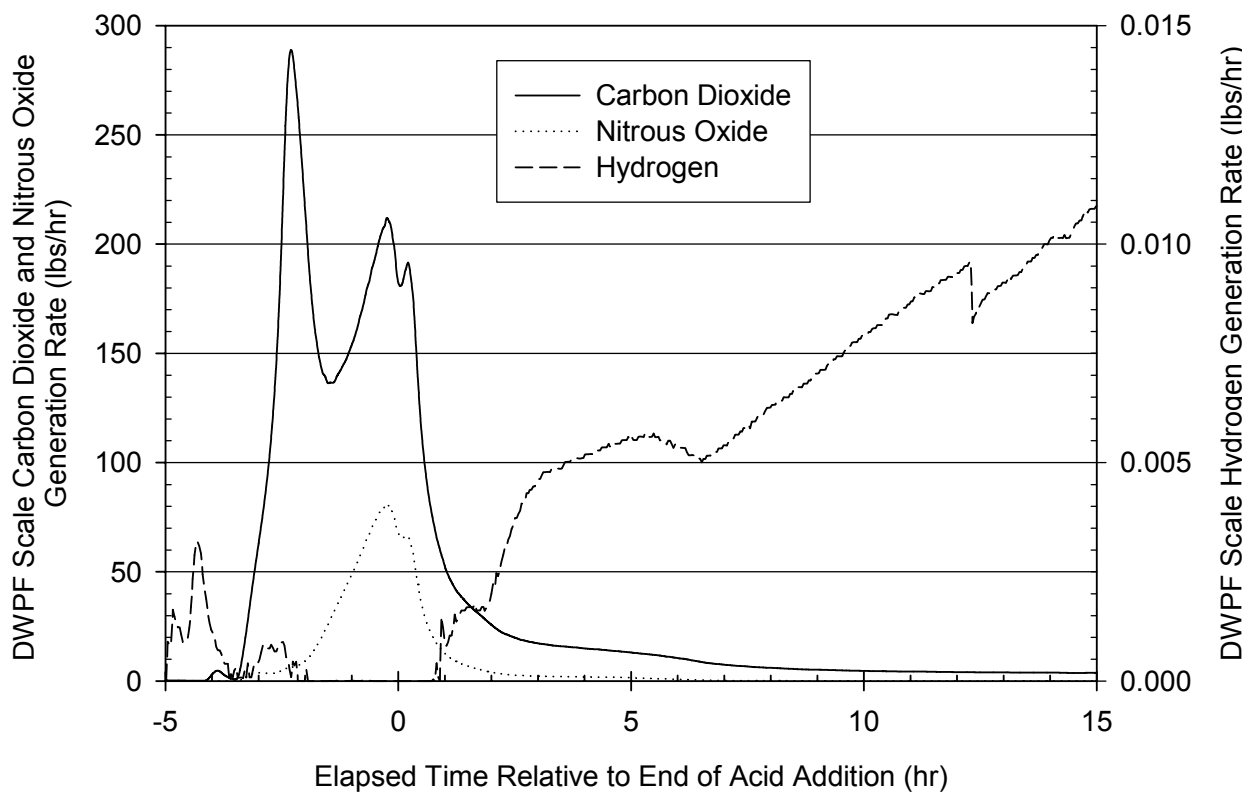

Figure 3-2. Gas Generation during the SB2/3 SRAT Cycle

Figure 3-3 shows a comparison between the SB2/3 and SB3 SRAT cycle hydrogen generation rates. Except for the distinct hydrogen peak in the SB3 cycle, rates are comparable. SB3 had a larger total acid addition than SB2, 2.3 vs. 1.7 moles acid per liter of sludge, respectively, and more residual formate in the final SRAT product, 61,700 vs. $54,700 \mathrm{mg} / \mathrm{kg}$ slurry, respectively, than the blend sample product. The large initial hydrogen peak observed in SB3, as compared to the SB2/3 SRAT cycle, may also be due to a difference in the noble metal content of the two sludges. 
WSRC-TR-2004-00097

Revision 0

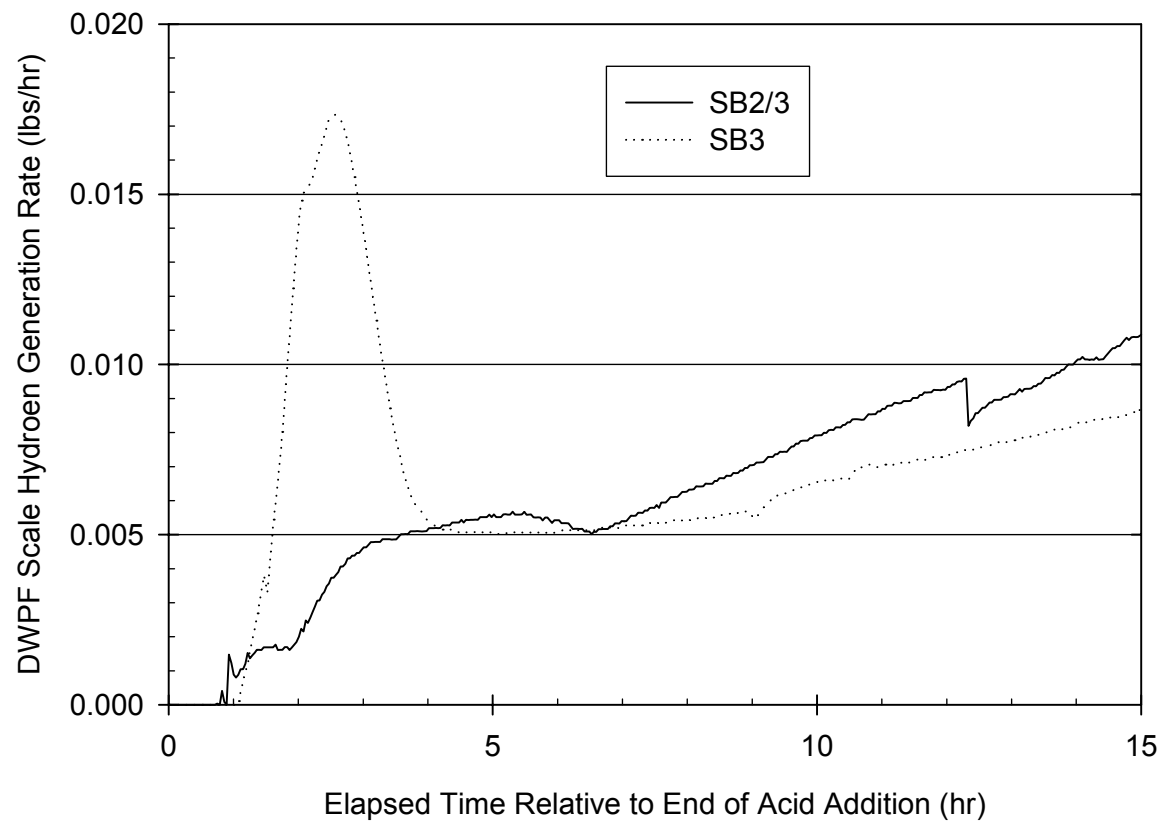

Figure 3-3. Comparison of SB2/3 and SB3 SRAT Cycle Hydrogen Generation Rates

For comparison, the noble metal contents ${ }^{\mathrm{c}}$ determined for the SB2 and SB3 Qualification samples along with an estimate for the SB2/3 blend are given in Table 3-7. While the SB2/3 blend was made with a 2003 sample of SB2, rather then the 2001 SB2 Qualification sample, in all likelihood the noble metal contents are similar. With the exception of $\mathrm{Rh}[+9 \%]$, SB2 noble metal content of the solids is lower than in SB3: Ag [-8\%], Pd [-47\%], and $\mathrm{Ru}[-9 \%]$. In all cases the SB2/3 blend is estimated to have lower noble metal concentrations than that observed for the SB3 Qualification sample.

Table 3-7. Comparison of Noble Metal Levels between SB2 and SB3 Qualification Samples

\begin{tabular}{cccc}
\hline Element & $\begin{array}{c}\text { 2001 SB2 } \\
\text { Qualification } \\
\text { Sample }^{\mathbf{2 3}}\end{array}$ & $\begin{array}{c}\text { 2003 SB3 } \\
\text { Qualification } \\
\text { Sample }^{\mathbf{1}}\end{array}$ & $\begin{array}{c}\text { SB2/3 Blend } \\
\text { (Estimated) }\end{array}$ \\
\hline Wt. \% Ag & 0.0106 & 0.0115 & - \\
Wt. \% Pd & 0.000885 & 0.00166 & - \\
Wt. \% Rh & 0.00777 & 0.00712 & - \\
Wt. \% Ru & 0.0328 & 0.0362 & - \\
$\mathrm{Ag}, \mathrm{mg} / \mathrm{L}$ & 24.0 & 38.2 & 32 \\
$\mathrm{Pd}, \mathrm{mg} / \mathrm{L}$ & 2.01 & 5.51 & 4.0 \\
$\mathrm{Rh}, \mathrm{mg} / \mathrm{L}$ & 17.6 & 23.6 & 21 \\
$\mathrm{Ru}, \mathrm{mg} / \mathrm{L}$ & 74.4 & 120 & 100 \\
\hline
\end{tabular}

\footnotetext{
"In this report, the term "noble metal" is loosely defined to include silver, Ag.
} 


\subsubsection{Nitrite, Formate, and Oxalate Destruction}

Several assumptions for anion destruction/conversion were made for the acid calculation (see Table 3-1). These assumptions involve nitrite to nitrate conversion, formate destruction, and oxalate destruction. Although the assumptions are based on overall processing (SRAT and SME cycles), SRAT cycle destruction/conversion is presented for information in Table 3-8. The oxalate destruction deserves comment. First the acid calculation is not influenced strongly by the oxalate destruction value. The calculated value in the table is based on overlapping values for starting $(919 \pm 141 \mathrm{mg} / \mathrm{kg}$ slurry) and ending ( $970 \pm 56 \mathrm{mg} / \mathrm{kg}$ slurry) oxalate concentrations. Aside from the uncertainty in the precision of the reported values, one must consider the $\pm 10 \%$ accuracy for routine analyses. Hence, an oxalate destruction rate on the order of $20 \%$ could easily be obscured.

Table 3-8. SRAT Cycle Nitrite to Nitrate Conversion, Percent Formate Destruction, and Percent Oxalate Destruction and Comparison to Acid Calculation Assumptions

\begin{tabular}{lcc}
\hline & Calculated & Assumed \\
\hline Nitrite Destruction & $100 \%$ & $100 \%$ \\
Nitrite to Nitrate Conversion (molar basis) & $59 \%$ & $38 \%$ \\
Formate Destruction & $16 \%$ & $16 \%$ \\
Oxalate Destruction & $0 \%$ & $25 \%$ \\
\hline
\end{tabular}

\subsubsection{Elements Dissolved From the Sludge During the SRAT Cycle}

During the SRAT cycle, elements dissolve from the sludge solids into the supernate as the vessel contents are acidified. The SRAT feed supernate was not analyzed for elemental composition, so an absolute comparison cannot be made to assess the impact of processing. For comparison purposes, SB3 data are provided along with those from the SB2/3 blend SRAT product in Table 3-9. Relative to the SB3 Qualification sample there was more soluble $\mathrm{Ca}, \mathrm{Mg}$, and $\mathrm{Na}$ but less soluble $\mathrm{Al}, \mathrm{Ni}$, and $\mathrm{U}$.

Table 3-9. Percent of Elements Soluble in the SRAT Cycle Feed and Product

\begin{tabular}{ccc}
\hline Element & $\begin{array}{c}\text { Percent } \\
\text { Soluble in } \\
\text { SB2/3 SRAT } \\
\text { Product }\end{array}$ & $\begin{array}{c}\text { Percent } \\
\text { Soluble in } \\
\text { SB3 SRAT } \\
\text { Product }\end{array}$ \\
\hline $\mathrm{Al}$ & 0.17 & 0.23 \\
$\mathrm{Ca}$ & 53 & 45 \\
$\mathrm{Fe}$ & 0.01 & 0.01 \\
$\mathrm{Mg}$ & 82 & 71 \\
$\mathrm{Mn}$ & 41 & 41 \\
$\mathrm{Na}$ & 100 & 74 \\
$\mathrm{Ni}$ & 1.8 & 2.4 \\
$\mathrm{U}$ & 54 & 67 \\
\hline
\end{tabular}


The values given in Table 3-9 are consistent with those trends shown in Figure 3-4, developed by Coleman et $\mathrm{al}^{24}$, for a SRAT product at a $\mathrm{pH}$ of 5.6. The soluble fraction is higher in the SB2/3 SRAT product for $\mathrm{Mn}$ and $\mathrm{Mg}$ than predicted below. Variations may be attributable to differences in the sludge composition in the Coleman work, as well as uncertainties in the absence of SRAT product solids analyses.

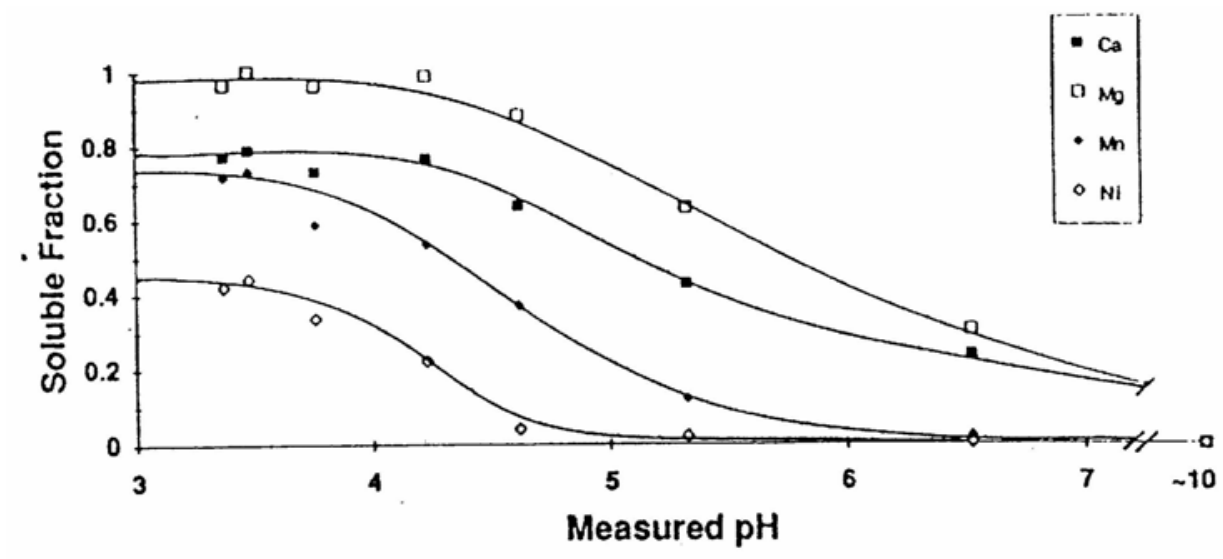

Figure 3-4. Effect of pH on Soluble Levels of Ca, Mg, Mn and Ni.

\subsubsection{Rheological Data on SB2/3 SRAT Product}

Rheological measurements were made on the blend product following SRAT processing. The up-flow curves for two replicate measurements are shown in Figure 3-5. As has been observed many times, the SRAT product sample is less viscous than the starting slurry. The average consistency, $4.8 \mathrm{cp}$, is at the minimum of the recommended DWPF operating region for SRAT product $(5-12 \mathrm{cp})$ and the average yield stress, $1.16 \mathrm{~Pa}$, is below the minimum recommended DWPF operating region for SRAT product $(1.5-5.0 \mathrm{~Pa})^{25}$.

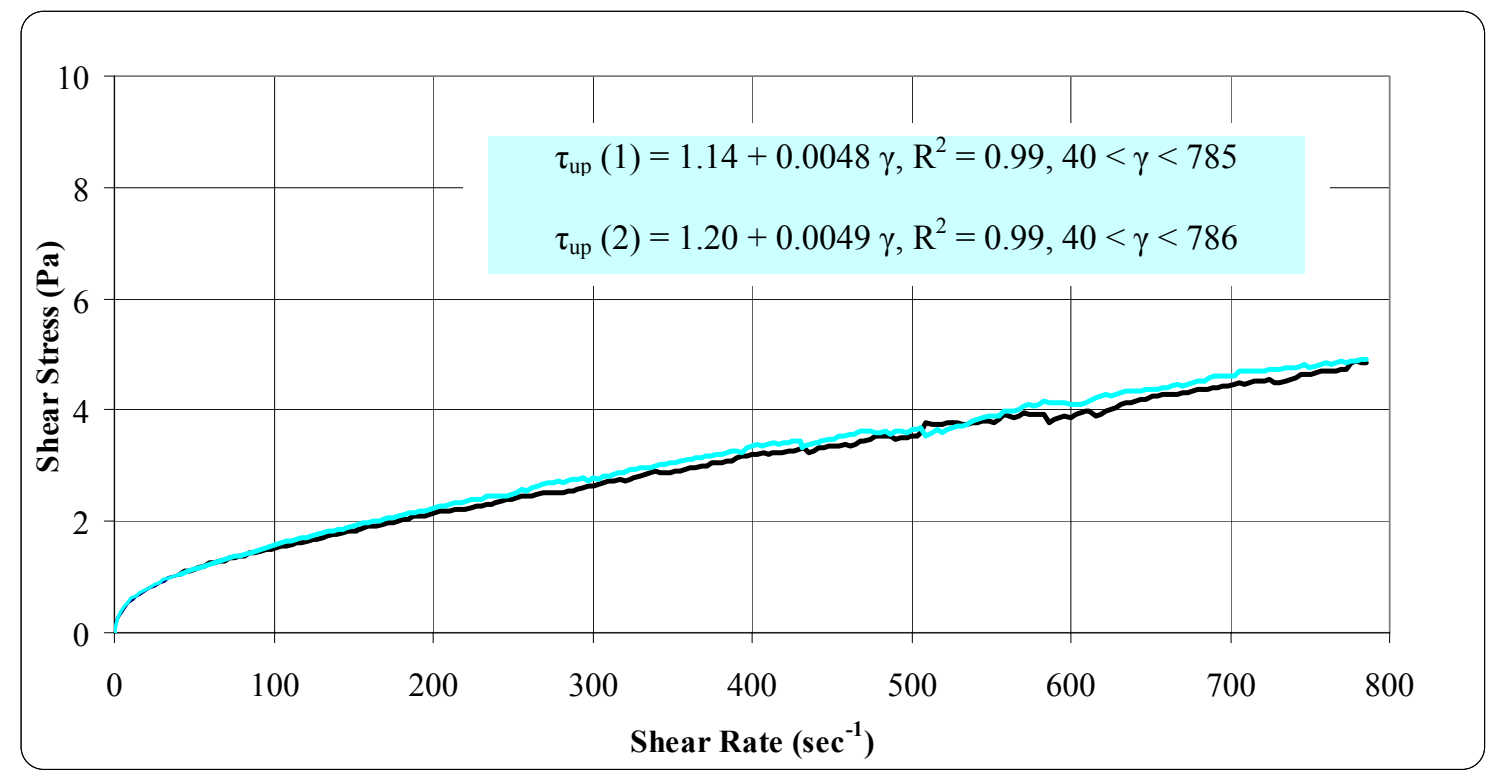

Figure 3-5. SB2/3 Blend SRAT Product Rheograms at $25^{\circ} \mathrm{C}$ 
WSRC-TR-2004-00097

Revision 0

This page intentionally left blank. 


\subsection{CONCLUSIONS}

- The SB2/3 blend supernate has a surface tension significantly higher than SB2 simulants and close to that of water.

- SB2/3 blend rheology is slightly more viscous and visually more cohesive than a SB3 sample alone.

- SRAT cycle processing of a SB2/3 blend was accomplished with no significant issues. Nitrite was destroyed at $140 \%$ of acid stoichiometry. Hydrogen generation was well within DWPF limits. Nitrous oxide generation was well within DWPF limits.

- Considerable soluble uranium was measured in the SRAT product, likely as a result of the final $\mathrm{pH}$ of the SRAT product.

- $\mathrm{SB} 2 / 3$ blend SRAT product is less viscous than the starting feed with both the consistency and yield stress below the recommended DWPF operating region. 
WSRC-TR-2004-00097

Revision 0

This page intentionally left blank. 


\subsection{RECOMMENDATIONS/PATH FORWARD}

The demonstration of simulated DWPF SRAT cycle processing of a radioactive SB2/3 blend based upon the expected tank volume ratios, at the time of the experimentation, in the SRNL Shielded Cells was accomplished successfully. It is recommended that DWPF could process a SB2/3 blend corresponding to that tested without issues related to off-gas generation in the SRAT.

As with the SB3 Qualification sample, appreciable soluble uranium was found in the SRAT product ${ }^{1}$. Initially this level of soluble uranium was believed to not have been previously observed, but we now believe it may be that it was not commonly measured or when it was measured, the final SRAT product $\mathrm{pH}$ was above 6 and appreciable soluble $\mathrm{U}$ was not produced. The source of this soluble uranium is not due solely to the simulated H-canyon plutonium transfer adjustments made to the SB3 Qualification sample prior to processing, since this accounts for only about $9 \%$ of the total uranium. Yet unpublished results from the study on the impact of uranium in SB2 processing indicate that freshly precipitated uranium is no more likely to be solubilized as a result of SRAT processing. The source of the soluble uranium is likely related to the final $\mathrm{pH}$ of the SRAT product rather than the relative age of the uranium species present.

It is prudent to process a sample of the final Tank 40/51 SB3 feed prepared in the Tank Farm when it becomes available later this FY to evaluate any processing issues and to determine the impact of the actual solids level on nitrite destruction. Simulant runs with higher solids levels could not destroy the nitrite at the same acid stoichiometry ${ }^{26}$. 
WSRC-TR-2004-00097

Revision 0

This page intentionally left blank. 


\subsection{REFERENCES}

${ }^{1}$ Pareizs, J. M., Koopman, D. C., Click, D. R., Cozzi, A. D., and Bibler, N. E. Sludge Batch 3 Qualification In The SRTC Shielded Cells, WSRC-TR-2004-00050, Savannah River Site, Aiken, SC 29808 (2004).

${ }^{2}$ Patel, P. M. Investigations of Sludge Batch 2 Processing Issues in DWPF Technical Task Request, HLW/DWPF/TTR-02-0035, Savannah River Site, Aiken, SC 29808 (2003).

${ }^{3}$ Rios-Armstrong, M. A. Sludge Batch 3 SRTC Shielded Cells Testing Technical Task Request, HLW/DWPF/TTR-03-0005, Rev. 1, Savannah River Site, Aiken, SC 29808 (2003).

${ }^{4}$ Fellinger, T. L. Task Technical and Quality Assurance Plan - Investigation of Sludge Batch 2 Processing Issues for DWPF - Shielded Cells Rheology Work, WSRC-RP-2003-00234, Savannah River Site, Aiken, SC 29808 (2003).

${ }^{5}$ Pareizs, J. M. Task Technical and Quality Assurance Plan for the Washing and Qualification of Sludge Batch 3 Radioactive Sludge Slurry, WSRC-RP-2003-00249, Rev. 1, Savannah River Site, Aiken, SC 29808 (2003).

${ }^{6}$ Pareizs, J. M. Analytical Study Plan for Qualification of Sludge Batch 3 Radioactive Sludge Slurry in the SRTC Shielded Cells, WSRC-RP-2003-00250, Rev. 1, Savannah River Site, Aiken, SC 29808 (2003).

${ }^{7}$ Fellinger, T. L. Status Report Summarizing the Shielded Cells Phase I Rheological Work for Sludge Batch 2, WSRC-TR-2003-00136, Savannah River Site, Aiken, SC 29808 (2003).

${ }^{8}$ Click, D. R. and Pareizs, J. M. Composition of SRAT Feed for the Sludge Batch 3 Acceptance Evaluation in the SRTC Shielded Cells, WSRC-RP-2003-01003, Savannah River Site, Aiken, SC 29808 (2003).

${ }^{9}$ Basic Data Report for DWPF Sludge Plant, DPST-80-1033, Rev. 91, Savannah River Site, Aiken, SC 29808 (1984).

${ }^{10}$ Waste Acceptance Criteria for Extended Sludge Processing Transfers to DWPF, X-SD-G-00004, Rev. 5, Savannah River Site, Aiken, SC 29808 (2004).

${ }^{11}$ Olney and Carlson, Chem. Engr. Progr. 43, 473 (1946).

${ }^{12}$ Kendall and Monroe, J. Am. Chem. Soc., 39, 1787, (1917).

${ }^{13}$ Fellinger, T. L. Summary of the Shielded Cells Phase I Sludge Batch 2 Rheology Work, WSRC-TR2003-00253, Savannah River Site, Aiken, SC, 29808 (2003).

${ }^{14}$ Herman, C. C. Chemical Process Cell Recommendation for Shielded Cells Qualification of Sludge Batch 3, Interoffice Memorandum, SRT-GPD-2003-00111, Savannah River Site, Aiken, SC 29808 (2003). 
${ }^{15}$ Herman, C. C., Koopman, D. C., Best, D. R., Snyder, T. K., and Williams, M. F. Sludge Batch 3 Simulant Flowsheet Studies: Final Phase SRAT/SME Results, WSRC-TR-2003-00422, Savannah River Site, Aiken, SC 29808 (2003).

${ }^{16}$ Jantzen, C. M., Koopman, D. C., Herman, C. C., Pickett, J. B., and Zamecnik, J. R. Electron Equivalence Model for Controlling REDuction/OXidation (REDOX) Equilibrium During High Level Waste (HLW) Vitrification, WSRC-TR-2003-00126, Savannah River Site, Aiken, SC 29808 (2003).

${ }^{17}$ Edwards, T. B. and Harbour, J. R. The Sensitivity of the Shielded Cells' Acid Addition Strategy to Measurement Uncertainties, Interoffice Memorandum SRT-SCS-2003-00037, Savannah River Site, Aiken, SC 29808 (2003).

${ }^{18}$ Baich, M. A., Herman, C. C., Koopman, D. C., Best, D. R., Snyder, T. K., Williams, M. F. Processing Options and Impact of Incorporation of ARP in the DWPF Process Flow Sheet, WSRC-TR-200300326, Savannah River Site, Aiken, SC 29808 (2003).

${ }^{19}$ Click, D. R. and Pareizs, J. M. Composition of SRAT Feed for the Sludge Batch 3 Acceptance Evaluation in the SRTC Shielded Cells, WSRC-RP-2003-01003, Rev. 0, Savannah River Site, Aiken, SC 29808 (2003)

${ }^{20}$ Bannochie, C. J. Run Plan for the SB2/SB3 SRAT Run in the SRTC Shielded Cells Facility, SRT-GPD2003-00153, Savannah River Site, Aiken, SC 29808 (2003).

${ }^{21}$ Peeler, D. K., Bibler, N. E., and Edwards, T. B., An Assessment of the Impacts of Adding Am/Cm and $\mathrm{Pu} / \mathrm{Gd}$ Waste Streams to Sludge Batch 3 (SB3) on DWPF $\mathrm{H}_{2}$ Generation Rates and Glass Properties, WSRC-TR-2002-00145, Savannah River Site, Aiken, SC 29808 (2002).

${ }^{22}$ Smith, R. M. and Martell, A. E. Critical Stability Constants, Vol. 4, Plenum Press, New York, (1976).

${ }^{23}$ Fellinger, T. L., Pareizs, J. M., Bibler, N. E., Cozzi, A. D., and Crawford, C. L. Confirmation Run of the DWPF SRAT Cycle Using the Sludge Only Flowsheet With Tank 40 Radioactive Sludge and Frit 200 in the Shielded Cells Facility, WSRC-TR-2002-00076, Savannah River Site, Aiken, SC 29808 (2002).

${ }^{24}$ Coleman, C. J., Bibler, N. E., Ferrara, D. M., and Siegwald, S. F. Reaction of Formic and Nitric Acids with Savannah River Site Radioactive HLW Sludge in the DWPF Pretreatment Steps, Nuclear and Hazardous Waste Management-Spectrum 94, pages 737-741, August 1994.

${ }^{25}$ Technical Data Summary for the Defense Waste Processing Facility: Sludge Plant, DPSTD-80-38-2, Savannah River Site, Aiken, SC 29808 (1980).

${ }^{26}$ Baich, M. A., Best, D. A., Snyder, T. K., and Williams, M. F. Sludge Batch 2/3 Blend Flowsheet Simulations: Determinations of Acid Addition Window, WSRC-TR-2004-00042, Savannah River Site, Aiken, SC 29808 (2004). 


\subsection{ACKNOWLEDGEMENTS}

The authors would like to acknowledge the support of the SRNL Shielded Cells technicians and supervision. We would also like to thank Dr. Damon Click for aqua regia preparations, as well as oxalate and sulfate data on the SB2/3 blend SRAT feed; Mr. Erich Hansen for rheology data on the SB2/3 blend feed; and Ms. Terri Fellinger for rheology data on the SB2/3 blend SRAT product and elemental analyses of archived SB2 (2003) SRAT product supernate. Additionally, the supplemental support provided by ITS technicians to move samples and prepare standards is greatly appreciated. 
WSRC-TR-2004-00097

Revision 0

This page intentionally left blank. 
Densities of SRAT feed and product slurry and SRAT product supernate - At least triplicate analyses of the slurry samples and filtered supernate samples were accomplished in the following manner. Sealed pipette tips were calibrated by weighing the pipette tips empty, filling them with water and weighing again. The temperature of the water was noted and used to obtain the density of the water from reference sources. The volume of each pipette tip was obtained by dividing the measured weight of the water by the density. Each pipette tip was labeled for traceability. The calibrated pipettes were then used in the shielded cells with radioactive supernate and sludge slurry samples. For both the slurry and supernate, three or more replicate measurements were done. In each measurement, an empty pipette tip was weighed, filled with slurry or supernate and then re-weighed. The measured sample weight was then divided by the calibrated volume of the pipette tip to obtain the density.

Density of the SRAT feed supernate - A $10.00 \mathrm{~mL}$ pycnometer was used to measure the density. Only a single measurement was made at the time.

Weight percent solids of slurry and supernate - Triplicate analyses of a standard, the slurry samples and filtered supernate were accomplished using ADS procedure 2284 and in the following manner. Clean and dry PMP beakers were labeled with identifying numbers and weighed. Approximately $3 \mathrm{~mL}$ of supernate, slurry or standard solution (15 $\mathrm{wt} \% \mathrm{NaCl}$ solution) was added to separate pre-weighed beakers. The samples were dried in the oven at $115^{\circ} \mathrm{C}$ for at least 8 hours, removed and allowed to cool for 10-15 minutes and re-weighed. The drying and weighing cycles continued until consecutive weights for each vessel did vary by more than $0.01 \mathrm{~g}$. The weight percent total solids (TS) is [the last dry weight - empty weight]/[full weight - empty weight]*100. The weight percent insoluble solids (IS) were calculated according to the following equation. IS $=\mathrm{TS}-(100-\mathrm{TS}) *(\mathrm{SS} / 100) /(1-\mathrm{SS} / 100)$ where SS $=$ weight percent soluble solids in the filtered solution of the sample.

Anion and elemental analysis of supernate - Triplicate analyses were done on filtered supernate samples. Three shielded polyethylene bottles were weighed and de-ionized water was added to the bottle using a calibrated pipette and the bottle was re-weighed. The bottles were taken into the shielded cells weighed and $0.5 \mathrm{~mL}$ to $2 \mathrm{~mL}$ of sample supernate was added using a calibrated pipette and finally the bottles were weighed again. The total amount of supernate added to the bottles was adjusted to make approximately a 5X (SRAT feed) or 20X (SRAT product) dilution of the supernate. The SRAT feed and product samples were submitted for ion chromatography and SRAT product samples for inductively coupled plasma - atomic emission spectroscopy.

Elemental analysis of total solids in SRAT feed - Dried slurry solids were digested using two different types of dissolutions (Aqua Regia and Sodium Peroxide Fusion) and from each dissolution, four samples were submitted for inductively coupled plasma atomic emission spectroscopy. ADS procedure 2226 was used for the aqua regia dissolutions and ADS procedure 2502 was used for the sodium peroxide fusion dissolutions. Only the aqua regia dissolutions results were deemed acceptable due to poor standards recoveries in the sodium peroxide fusion samples.

Anion and elemental analysis of SRAT product slurry - Triplicate analyses were done on slurry samples. Approximately $1 \mathrm{~g}$ of well mixed radioactive slurry was added to a PMP beaker. Three slurries were struck first with $2 \mathrm{~mL}$ of concentrated hydrochloric acid, swirled for several minutes and then struck with $2 \mathrm{~mL}$ of concentrated nitric acid before transfer to a $100 \mathrm{~mL}$ volumetric and diluted with de-ionized water to produce a $100 \mathrm{X}$ dilution. Three additional slurries were diluted directly to $100 \mathrm{~mL}$ with de-ionized water. Approximately $10 \mathrm{~mL}$ of each sample was transferred to a shielded polyethylene bottle and submitted for ion chromatography and inductively coupled plasma - atomic emission spectroscopy. 
Carbonate content of slurry - Triplicate analyses of carbonate content were done. Approximately $0.5 \mathrm{~g}$ of well mixed radioactive slurry was added to each of three bottles containing $10 \mathrm{~g}$ of de-ionized water. The bottles were removed from the shielded cells and submitted for total organic carbon and total inorganic carbon analysis using a high temperature total organic carbon analyzer.

Total base of slurry - Triplicate analysis of total base was done. This was determined via an inflection end point acid titration to $\mathrm{pH} 7$. 